\title{
Delivering pharmacogenetic testing in a primary care setting
}

This article was published in the following Dove Press journal:

Pharmacogenomics and Personalized Medicine

19 September 2013

Number of times this article has been viewed

\author{
Rachel Mills' \\ Deepak Voora ${ }^{1,2}$ \\ Bruce Peyser ${ }^{3}$ \\ Susanne B Haga ${ }^{1,2}$ \\ 'Duke Institute for Genome Sciences \\ and Policy, ${ }^{2}$ Duke Center for \\ Personalized and Precision Medicine, \\ ${ }^{3}$ Duke University Medical Center, \\ Pickett Road Primary Care Clinic, \\ Duke University, Durham, NC, USA
}

\begin{abstract}
Pharmacogenetic testing refers to a type of genetic test to predict a patient's likelihood to experience an adverse event or not respond to a given drug. Despite revision to several labels of commonly prescribed drugs regarding the impact of genetic variation, the use of this testing has been limited in many settings due to a number of factors. In the primary care setting, the limited office time as well as the limited knowledge and experience of primary care practitioners have likely attributed to the slow uptake of pharmacogenetic testing. This paper provides talking points for primary care physicians to discuss with patients when pharmacogenetic testing is warranted. As patients and physicians become more familiar and accepting of pharmacogenetic testing, it is anticipated that discussion time will be comparable to that of other clinical tests.
\end{abstract}

Keywords: pharmacogenetics, primary care, pharmacogenetic testing, patient education

\section{Introduction}

Pharmacogenetic (PGx) testing is a type of genetic test that assesses a patient's risk of an adverse response or likelihood to respond to a given drug, informing drug selection and dosing. ${ }^{1}$ As a pillar of the personalized medicine movement, PGx testing is anticipated to be important across all medical specialties, ${ }^{2}$ but particularly in primary care, where the majority of all drug prescriptions are written. ${ }^{3}$ It has been estimated that many of the drugs commonly prescribed by primary care practitioners (PCPs) such as fluoxetine, metoprolol, warfarin, and simvastatin are affected by PGx variation. ${ }^{4,5}$ Although several different strategies of delivering PGx testing have been proposed or are being investigated, ${ }^{6-8}$ at present, there is little clarity on which health professionals should order PGx testing, at what stage during treatment testing should be ordered, how best to communicate results to patients, and where results should be stored to inform future therapeutic decision making. ${ }^{9}$ Patients prefer receiving PGx test results from a familiar provider whom they trust such as a PCP.9,10 however, several factors have contributed to the slow integration of PGx testing in the primary care setting, ${ }^{11,12}$ including limited time as well as familiarity and experience with PGx testing. ${ }^{13-15}$ Because PGx testing is a relatively new field and many PCPs are unfamiliar with many of the basic tenets of the field, ongoing learning opportunities and/or faculty development would enable PCPs to feel more comfortable with the topic, and presumably engage in more effective communication with patients, and more appropriate use of testing. This paper suggests key elements to be discussed with patients prior to testing and when reporting test results to assist PCPs while recognizing some of the practical limitations in the primary care setting.
Correspondence: Susanne B Haga Institute for Genome Sciences and Policy/Center for Personalized an 304 Research Drive, Box 9014I, Durham, NC 27708, USA

Tel +l 9196840325

$\mathrm{Fax}+19196136448$

Email susanne.haga@duke.edu 


\section{Pre-test communication}

Education is a hallmark of the patient-provider relationship ${ }^{16}$ and new technologies will likely warrant additional patient education until familiarity increases. PGx testing is often ideally considered as a preventative clinical test with limited risks, ${ }^{17,18}$ and therefore the amount of information discussed prior to testing is believed to be much less than required for a disease-based genetic test. ${ }^{9}{ }^{19}$ However, the novelty of PGx testing and the fact that it is a DNA-based test necessitate some discussion to facilitate informed decision making. In general, written informed consent is not typically recommended or obtained, ${ }^{20-24}$ although some testing laboratories may require it as they do for other types of genetic testing. While some tools and educational interventions have been developed to help PCPs deliver genetic testing services, none are specific to PGx testing. ${ }^{25-28}$

Some patients have expressed interest in receiving information about PGx testing. ${ }^{10,29}$ However, PGx is a relatively new field that many providers have little experience with. ${ }^{14,15}$ Therefore, four main elements of PGx testing to be discussed prior to testing are suggested: (1) the purpose of testing and role of genes in drug response; (2) test risks and benefits, limitations, and alternatives; (3) emphasis that testing involves analysis of DNA; and (4) future benefits of PGx testing. As with any other clinical test, health literacy (including numeracy) may affect patients' understanding of the purpose, risks, and benefits of PGx testing and/or the actual results. ${ }^{30}$
Some of this information can be provided through patient educational materials and subsequent questions or areas of uncertainty may be discussed at a follow-up visit (Table 1). Therefore, prepared text and information relevant to the discussion of PGx testing should be readily available so that PCPs can quickly share pertinent information.

\section{Review purpose of test for the given prescription}

The purpose of PGx testing is to determine the risk of side effects and/or likelihood of effectiveness of a given medication. ${ }^{1}$ Physicians are often asked about side effects of prescribed drugs and factors that may alter the effectiveness of a drug, and if PGx testing is an option, it should be part of that conversation. In particular, PCPs can point out that a small change in a gene important in metabolizing or transporting (or other function) occurs in a subset of patients and a test is available to detect this change. The physician should briefly describe the possible outcomes regarding adjusting dose or drug selection based on the test result. Details such as gene name, specific variation, or gene function would be unnecessary.

\section{Discuss risks/benefits, limitations, and alternative options}

It should be emphasized that identification of a genetic change or metabolic activity does not necessarily indicate

Table I A sample of online resources for patients and health professionals

\begin{tabular}{|c|c|}
\hline Patient resources & Professional resources \\
\hline National Institute of General Medical Sciences: Frequently & US Food and Drug Administration: Table of PGx Biomarkers \\
\hline Asked Questions about Pharmacogenomics (http://www.nigms.nih.govl & in Drug Labels (http://www.fda.gov/Drugs/ScienceResearch/ \\
\hline Research/FeaturedPrograms/PGRN/Background/pgrn_faq.htm) & ResearchAreas/Pharmacogenetics/ucm083378.htm) \\
\hline National Institutes of Health Genetics Home Reference: & PharmGKB \\
\hline $\begin{array}{l}\text { What Is Pharmacogenomics? (http://ghr.nlm.nih.gov/handbook/ } \\
\text { genomicresearch/pharmacogenomics) }\end{array}$ & (http://www.pharmgkb.org/) \\
\hline National Institutes of Health, National Institute for General & PharmGKB: Clinical Pharmacogenetics Implementation Consortium \\
\hline Medical Sciences, Medicines for You: Studying How Your & (CPIC) Guidelines (http://www.pharmgkb.org/page/cpic) \\
\hline \multicolumn{2}{|l|}{$\begin{array}{l}\text { Genes can Make a Difference. Available at } \\
\text { (http://publications.nigms.nih.gov/medsforyou/) }\end{array}$} \\
\hline Mayo Clinic: Personalized Medicine and Pharmacogenomics & National Genetics and Education Development Centre: \\
\hline (http://www.mayoclinic.com/health/personalized-medicine/CA00078) & $\begin{array}{l}\text { Pharmacogenetics in Healthcare (http://www.geneticseducation.nhs. } \\
\text { uk/pharmacogenomics-in-healthcare) }\end{array}$ \\
\hline $\begin{array}{l}\text { Duke University Institute of Genome Sciences and Policy } \\
\text { (http://www.genome.duke.edu/research/genomic-medicine/ } \\
\text { areas/pharmacogenomics/education/consumers/) }\end{array}$ & $\begin{array}{l}\text { UK Pharmacogenetics and Stratified Medicine Network } \\
\text { (http://www.uk-pgx-stratmed.co.uk/) }\end{array}$ \\
\hline University of Utah Genetic Science Learning Center: Personalized & Centre for Pharmacy Postgraduate Education: Pharmacogenetics \\
\hline Medicine (Pharmacogenomics) (http://learn.genetics.utah.edu/ & E-Learning Programme (http://www.cppe.ac.uk/e-learning/ \\
\hline content/health/pharma/) & pharmacogenetics/flash/pharmaco-elp.swf) \\
\hline Wellcome Trust Sanger Institute & University of California San Diego Pharmacogenomics Education \\
\hline (http://www.yourgenome.org/sis/pharm/) & Program (http://pharmacogenomics.ucsd.edu/) \\
\hline
\end{tabular}


an absolute diagnosis of non-response or that a side effect will or will not occur upon use of a given drug. The scientific basis of the role of genes in drug response is incomplete and rapidly changing and other factors may affect drug response. In addition, although the physical risks are no greater than for any other clinical test, it should be mentioned that federal ${ }^{1 a w^{31}}$ prohibits any use of genetic information by health insurers and employers, though other groups may still use this information (eg, life insurers and the military). Another issue PCPs may face is patient confusion as a "normal" PGx test result doesn't necessarily mean the patient is not at risk for adverse events or non-response because current tests only capture known variants in known genes. Additionally, other factors such as cost of testing, insurance coverage, and risk of delay of treatment while waiting for testing to be completed may influence the patient's decision to have testing. If the patient declines to have testing, the PCP should discuss alternative interventions to limit risk of side effects or non-response as medically warranted. For example, initial dose selection can be minimized, dose escalations can be modest, a review of concomitant drugs for potential drug-drug interactions can be conducted, and selection of alternate drugs in the same class that are less susceptible to PGx interactions may be considered.

\section{Emphasize the genetic basis of PGx testing}

It is prudent to disclose that this is a DNA-based test and that specific gene(s) associated with drug response will be analyzed, particularly if one prefers to describe the test as a "drug response test" instead of using the unfamiliar and imposing term of "PGx" testing. PGx tests are considered more comparable to non-genetic clinical tests given its specific purposes and low psychosocial risk, ${ }^{17,18}$ but given some of the public fears associated with genetic testing, ${ }^{32,33}$ it should also be emphasized that the DNA sample will only be analyzed for the specific genes (unless a broader type of test is ordered) and that it will be destroyed after testing as per the laboratory's policies. The effect of a PGx variant would only affect family members if they are exposed to the same drugs, a strong possibility if the disease is due to shared environmental and/or genetic factors. Therefore, potential familial implications of a PGx test result should be mentioned.

\section{Discuss future benefits of testing}

Given that many commonly prescribed drugs are impacted by a handful of genes such as drug transporters or drug metabolizing enzymes, it is highly likely that the result of one PGx test will be useful for future treatments. Thus, the PGx test results are not only important for the drug which prompted the testing, but potentially for other drugs prescribed in the future. Therefore, it should be emphasized that a test result can help inform other treatment decisions in the future and should be shared with other providers or perhaps the patient's pharmacist. This will help reduce redundant testing and encourage consideration of the existing test results by other prescribing providers. Conceivably, with electronic health records, the sharing of this information might not even necessarily require direct patient or physician involvement. Furthermore, with increased use of PGx testing over time and greater accessibility of results through electronic health records, the ease of sharing genetic information amongst family members may increase, particularly if they are exposed to the same drugs.

\section{Post-testing: communicating test results}

Due to the relatively short period of time that PGx tests have been used, there are little data regarding how patients process and respond to PGx test results. Although patients have struggled with comprehending information about genetic diseases and risk, ${ }^{34,35} \mathrm{PGx}$ testing is not typically presented as risks but rather as the presence or absence of a genetic variation that has been associated with a given drug response, unlike other genomic disease risk assessments. ${ }^{36,37}$ While the lack of certainty regarding the likelihood to develop an adverse response or not to respond to a drug at all may result in some stress, the presentation of the test result as the presence or absence of a genetic variant or as a phenotype (eg, normal metabolism) may result in better understanding. Therefore, five strategies to improve patient comprehension of PGx test results and its significance to their treatment are suggested: (1) use effective risk communication strategies; (2) inform patients what, if any, changes will be made to the prescribed drug; (3) re-emphasize relevance of test results for future treatments; (4) make referrals as necessary; and (5) provide a patient letter. Additionally, Table 2 provides suggested text for discussion using the example of PGx testing for simvastatin to illustrate how these key elements may be communicated to patients.

\section{Use effective risk communication strategies}

As with any clinical test, the communication of test results should be tailored to the patient's needs and concerns since not all risk information may be informative or useful to patients. ${ }^{38}$ For PGx testing, it is probably less important for patients to 
Table 2 Sample text based on the proposed strategy for post-testing communication using the example of SLCOIBI for simvastatin (statin-induced myalgia has been associated with a variant in the hepatic transporter gene, SLCOIBI, particularly in patients prescribed simvastatin and to a lesser degree, atorvastatin $)^{55,56}$

\begin{tabular}{|c|c|c|c|}
\hline & \multicolumn{3}{|c|}{ PGx test results and possible clinical implications } \\
\hline & $\begin{array}{l}\text { Genotype TT: this } \\
\text { genotype is associated } \\
\text { with normal activity } \\
\text { and a decreased risk for } \\
\text { simvastatin-associated } \\
\text { myopathy }\end{array}$ & $\begin{array}{l}\text { Genotype TC: this genotype } \\
\text { is associated with intermediate } \\
\text { activity and an increased risk } \\
\text { for simvastatin-associated } \\
\text { myopathy. A decreased dose } \\
\text { or alternate drug may be } \\
\text { warranted }\end{array}$ & $\begin{array}{l}\text { Genotype CC: this genotype is } \\
\text { associated with low activity and a } \\
\text { highly increased risk for simvastatin- } \\
\text { associated myopathy. A decreased } \\
\text { dose or alternate drug may be } \\
\text { warranted. Routine creatine kinase } \\
\text { surveillance may also be considered }\end{array}$ \\
\hline $\begin{array}{l}\text { Use effective risk } \\
\text { communication strategies } \\
\text { in discussing PGx results }\end{array}$ & $\begin{array}{l}\text { "The drug response test did } \\
\text { not identify any changes } \\
\text { in a gene that affects how } \\
\text { simvastatin is broken down." }\end{array}$ & $\begin{array}{l}\text { "The drug response test found that } \\
\text { you have a change in a gene that } \\
\text { affects how simvastatin is broken } \\
\text { down." }\end{array}$ & $\begin{array}{l}\text { "The drug response test found that you } \\
\text { have a change in a gene that affects how } \\
\text { simvastatin is broken down." }\end{array}$ \\
\hline $\begin{array}{l}\text { Inform patients what, } \\
\text { if any, changes will be } \\
\text { made to the prescribed } \\
\text { drug }\end{array}$ & $\begin{array}{l}\text { "Based on these test results, } \\
\text { we will have you continue } \\
\text { to take simvastatin at your } \\
\text { current dose." }\end{array}$ & $\begin{array}{l}\text { "Based on these results, we will } \\
\text { decrease your dose and continue } \\
\text { to monitor your cholesterol." } \\
\text { "Based on these results, I am going } \\
\text { to prescribe a different medication } \\
\text { to help regulate your cholesterol." } \\
\text { "Based on these results, we will } \\
\text { closely monitor you; it is important } \\
\text { that you immediately report any } \\
\text { muscle pain or weakness while you } \\
\text { continue to take simvastatin." }\end{array}$ & $\begin{array}{l}\text { "Based on these results, we will decrease } \\
\text { your dose and continue to monitor your } \\
\text { cholesterol." } \\
\text { "Based on these results, I am going to } \\
\text { prescribe a different medication to help } \\
\text { regulate your cholesterol." } \\
\text { "Based on these results, we will closely } \\
\text { monitor you; it is important that you } \\
\text { immediately report any muscle pain or } \\
\text { weakness while you continue to take } \\
\text { simvastatin." }\end{array}$ \\
\hline $\begin{array}{l}\text { Emphasize importance } \\
\text { of relevance of test results } \\
\text { for future treatments }\end{array}$ & $\begin{array}{l}\text { "At this time, simvastatin } \\
\text { is the only medicine related } \\
\text { to the gene we tested. } \\
\text { However, it is very likely that } \\
\text { more medicines will be developed } \\
\text { or more discoveries will be made } \\
\text { about this gene. Therefore it is } \\
\text { important for you to remember } \\
\text { this result and share it with } \\
\text { other prescribing doctors." }\end{array}$ & $\begin{array}{l}\text { "At this time, simvastatin is the } \\
\text { only medicine related to the gene } \\
\text { we tested. However, it is very } \\
\text { likely that more medicines will be } \\
\text { developed or more discoveries } \\
\text { will be made about this gene. } \\
\text { Therefore it is important for } \\
\text { you to remember this result and } \\
\text { share it with other prescribing } \\
\text { doctors." }\end{array}$ & $\begin{array}{l}\text { "At this time, simvastatin is the only } \\
\text { medicine related to the gene we tested. } \\
\text { However, it is very likely that more } \\
\text { medicines will be developed or more } \\
\text { discoveries will be made about this gene. } \\
\text { Therefore it is important for you to } \\
\text { remember this result and share it with } \\
\text { other prescribing doctors." }\end{array}$ \\
\hline
\end{tabular}

Note: Sample text based on PharmGKB. ${ }^{57}$

understand their specific genotype, and more important to present the significance of the results (ie, slower than normal ability to break down this drug). Risk communication for PGx results should focus on the likelihood of a particular drug causing side effects and whether or not the drug will be effective. When communicating risk, it is important to be cognizant of potential negative connotations associated with certain commonly used phenotypic descriptors (eg, "poor" metabolizer). As with other medical information, use of medical jargon should be limited or defined if used.

\section{Inform patients what, if any, changes will be made to the prescribed drug}

If adjustments to drug selection or dosing are warranted based on the patient's PGx test result, discuss what changes will be made and the purpose of the change.

\section{Re-emphasize relevance of test results for future treatments}

PCPs should remind patients of the potential significance of the current PGx test result for future treatments and encourage sharing of the test result with other providers. Studies have reported that some individuals that had PGx testing recognized the implications of testing for future $\operatorname{drugs}^{39}$ and asked about the future use of other drugs after receiving results. ${ }^{17}$ Ideally, PGx test results should automatically be included in the medical record just as a standard complete blood count or pathology result is appended to the record. Inaccessible PGx results could lead to much confusion, frustration, and potentially poorer patient and family outcomes. Patients can share the patient summary letter or a copy of the test report, or some type of summary record of their results kept on a card or something akin 
to an immunization record, particularly if they have had PGx testing for different genes. Patients have indicated their willingness to keep their results on a card or other convenient device. ${ }^{40}$

\section{Make referrals as necessary}

Some PGx variants not only affect drug responses but also disease risk. ${ }^{41-43}$ For example, a variant in the apolipoprotein $\mathrm{E}(A p o E)$ gene has been linked to low-density lipoprotein response to statins,${ }^{44}$ with an ancillary effect on Alzheimer's disease risk. ${ }^{44,45}$ Some studies have suggested that providers should disclose the existence of ancillary risk information to enable patients to decide if they would want to learn of these results. ${ }^{46,47}$ If a PGx variant has an ancillary effect, the benefits of knowing the PGx variant to inform treatment should outweigh the risks of revealing a potential disease risk variant. In the case of $A p o E$, the effect on lowdensity lipoprotein cholesterol lowering appears minimal, and therefore the benefit of the PGx knowledge would not be greater than the risks and additional efforts associated with genetic counseling and testing for Alzheimer's disease. Another approach, though controversial, is to not report individual genotype in the test results and instead simply report the expected phenotype, eg, poor response to statin, increased dose recommended. Because genetics professionals are likely better trained to discuss disease risk information, it may be prudent for PCPs to refer their patient to a genetics professional if a test with ancillary disease information is ordered. Additionally, genetic counseling may be beneficial for patients that exhibit difficulty in understanding or coping with the results. ${ }^{39}$ Therefore, to assist PCPs, it would be helpful to have a simple process established for genetics referrals when complex situations or results come back. Such a process may enhance both patient and provider acceptance of PGx and other types of genetic testing.

\section{Provide a patient letter}

It is common practice for genetic counselors to send a follow-up summary letter, reviewing the reason for testing, the name/type of test ordered, the results of the test, the implications of those results, and recommendations for follow-up. The letter may also include educational resources such as websites for patients to seek additional information if desired. Providing after-visit summaries is becoming more prevalent and useful in this increasing age of electronic health records for other medical specialties. Since it is not uncommon to deliver test results over the phone or via letter when follow-up visits cannot be scheduled in a timely manner or deemed unnecessary (eg, results are normal), some prepared text about PGx testing may help patients fully comprehend their results and PCPs quickly return patient test results (see Supplemental Figure). Particularly important for PGx testing, the letter may be shared with other providers providing treatment. ${ }^{48-51}$ Patient satisfaction and understanding of results received through other forms of communication have been shown to be comparable to those that receive results in-person. ${ }^{52-54}$

\section{Conclusion}

Given the limited time with patients in a primary care setting, the amount of information that can be conveyed to patients about PGx testing will be quite limited. The talking points provided in this paper should provide some guidance on the core elements needed to reach an informed decision about PGx testing. In combination with other resources, PCPs can adequately and effectively discuss PGx testing with their patients. As patient familiarity increases and PGx testing becomes standard of care, the amount of discussion will likely be substantially less, primarily limited to the results and its impact on drug selection and dosing.

\section{Disclosure}

The authors report no conflicts of interest in this work.

\section{References}

1. Wang L, McLeod HL, Weinshilboum RM. Genomics and drug response. N Engl J Med. 2011;364(12):1144-1153.

2. Manolio TA, Chisholm RL, Ozenberger B, et al. Implementing genomic medicine in the clinic: the future is here. Genet Med. 2013;15(4): 258-267.

3. CDC/NCHS. National Ambulatory Medical Care Survey: 2010 Summary Tables. Atlanta, GA: Centers for Disease Control and Prevention; 2010. Available from: http://www.cdc.gov/nchs/data/ahcd/namcs_ summary/2010_namcs_web_tables.pdf. Accessed August 1, 2013.

4. Frueh FW, Amur S, Mummaneni P, et al. Pharmacogenomic biomarker information in drug labels approved by the United States Food and Drug Administration: prevalence of related drug use. Pharmacotherapy. 2008;28(8):992-998.

5. Grice GR, Seaton TL, Woodland AM, McLeod HL. Defining the opportunity for pharmacogenetic intervention in primary care. Pharmacogenomics. 2006;7(1):61-65.

6. Crews KR, Hicks JK, Pui CH, Relling MV, Evans WE. Pharmacogenomics and individualized medicine: translating science into practice. Clin Pharmacol Ther. 2012;92(4):467-475.

7. Pulley JM, Denny JC, Peterson JF, et al. Operational implementation of prospective genotyping for personalized medicine: the design of the Vanderbilt PREDICT project. Clin Pharmacol Ther. 2012;92(1):87-95.

8. Mills R, Haga SB. Clinical delivery of pharmacogenetic testing services: a proposed partnership between genetic counselors and pharmacists. Pharmacogenomics. 2013;14(8):957-968.

9. Fargher EA, Eddy C, Newman W, et al. Patients' and healthcare professionals' views on pharmacogenetic testing and its future delivery in the NHS. Pharmacogenomics. 2007;8(11):1511-1519. 
10. Payne K, Fargher EA, Roberts SA, et al. Valuing pharmacogenetic testing services: a comparison of patients' and health care professionals' preferences. Value Health. 2011;14(1):121-134.

11. Swen JJ, Guchelaar HJ. Just how feasible is pharmacogenetic testing in the primary healthcare setting? Pharmacogenomics. 2012;13(5): 507-509.

12. van Schie RM, de Boer A, Maitland-van der Zee AH. Implementation of pharmacogenetics in clinical practice is challenging. Pharmacogenomics. 2011;12(9):1231-1233.

13. Shields AE, Lerman C. Anticipating clinical integration of pharmacogenetic treatment strategies for addiction: are primary care physicians ready? Clin Pharmacol Ther. 2008;83(4):635-639.

14. Haga SB, Burke W, Ginsburg GS, Mills R, Agans R. Primary care physicians' knowledge of and experience with pharmacogenetic testing. Clin Genet. 2012;82(4):388-394.

15. Stanek EJ, Sanders CL, Taber KA, et al. Adoption of pharmacogenomic testing by US physicians: results of a nationwide survey. Clin Pharmacol Ther. 2012;91(3):450-458.

16. Bird J, Cohen-Cole SA. The three-function model of the medical interview. An educational device. Adv Psychosom Med. 1990;20:65-88.

17. Madadi P, Joly Y, Avard D, et al. The communication of pharmacogenetic research results: participants weigh in on their informational needs in a pilot study. J Popul Ther Clin Pharmacol. 2011;18:e152-e155.

18. Roses AD. Pharmacogenetics and the practice of medicine. Nature. 2000;405(6788):857-865.

19. Callard A, Newman W, Payne K. Delivering a pharmacogenetic service: is there a role for genetic counselors? J Genet Couns. 2012;21(4): 527-535.

20. Robertson JA. Consent and privacy in pharmacogenetic testing. Nat Genet. 2001;28(3):207-209.

21. Robertson JA, Brody B, Buchanan A, Kahn J, McPherson E. Pharmacogenetic challenges for the health care system. Health Aff (Millwood). 2002;21(4):155-167.

22. Woelderink A, Ibarreta D, Hopkins MM, Rodriguez-Cerezo E. The current clinical practice of pharmacogenetic testing in Europe: TPMT and HER2 as case studies. Pharmacogenomics J. 2006;6(1):3-7.

23. Hedgecoe A. "At the point at which you can do something about it, then it becomes more relevant": informed consent in the pharmacogenetic clinic. Soc Sci Med. 2005;61(6):1201-1210.

24. Hedgecoe AM. Context, ethics and pharmacogenetics. Stud Hist Philos Biol Biomed Sci. 2006;37(3):566-582.

25. Carroll JC, Rideout AL, Wilson BJ, et al. Genetic education for primary care providers: improving attitudes, knowledge, and confidence. Can Fam Physician. 2009;55(12):e92-e99.

26. Carroll JC, Wilson BJ, Allanson J, et al. GenetiKit: a randomized controlled trial to enhance delivery of genetics services by family physicians. Fam Pract. 2011;28(6):615-623.

27. Emery J, Walton R, Murphy M, et al. Computer support for interpreting family histories of breast and ovarian cancer in primary care: comparative study with simulated cases. BMJ. 2000;321(7252):28-32.

28. Watson E, Clements A, Yudkin P, et al. Evaluation of the impact of two educational interventions on GP management of familial breast/ ovarian cancer cases: a cluster randomised controlled trial. $\mathrm{Br} \mathrm{J} \mathrm{Gen}$ Pract. 2001;51(471):817-821.

29. Haddy CA, Ward HM, Angley MT, McKinnon RA. Consumers' views of pharmacogenetics: a qualitative study. Res Social Adm Pharm. 2010;6(3):221-231.

30. Lea DH, Kaphingst KA, Bowen D, Lipkus I, Hadley DW. Communicating genetic and genomic information: health literacy and numeracy considerations. Public Health Genomics. 2011;14(4-5):279-289.

31. The Genetic Information Nondiscrimination Act of 2008 [webpage on the Internet]. Washington, DC: US Equal Employment Opportunity Commission; 2008. Available from: http://www.eeoc.gov/laws/statutes/ gina.cfm. Accessed May 21, 2013.
32. Hall MA, McEwen JE, Barton JC, et al. Concerns in a primary care population about genetic discrimination by insurers. Genet Med. 2005;7(5):311-316.

33. Klitzman R. Views of discrimination among individuals confronting genetic disease. J Genet Couns. 2010;19(1):68-83.

34. Kaphingst KA, McBride CM, Wade C, et al. Patients' understanding of and responses to multiplex genetic susceptibility test results. Genet Med. 2012;14(7):681-687.

35. Klitzman RL. Misunderstandings concerning genetics among patients confronting genetic disease. J Genet Couns. 2010;19(5):430-446.

36. Bloss CS, Wineinger NE, Darst BF, Schork NJ, Topol EJ. Impact of direct-to-consumer genomic testing at long term follow-up. $J$ Med Genet. 2013;50(6):393-400.

37. 23 andme.com [homepage on the Internet]. Genetic testing for health, disease, and ancestry. 2007 [updated August 1, 2013]. Available from: http://23andme.com. Accessed July 17, 2013.

38. Zikmund-Fisher BJ. The right tool is what they need, not what we have: a taxonomy of appropriate levels of precision in patient risk communication. Med Care Res Rev. 2013;70(Suppl 1): $37 \mathrm{~S}-49 \mathrm{~S}$

39. Madadi P, Joly Y, Avard D, et al. Communicating pharmacogenetic research results to breastfeeding mothers taking codeine: a pilot study of perceptions and benefits. Clin Pharmacol Ther. 2010;88(6): 792-795.

40. Haga SB, Kawamoto K, Agans R, Ginsburg GS. Consideration of patient preferences and challenges in storage and access of pharmacogenetic test results. Genet Med. 2011;13(10):887-890.

41. Haga SB, Burke W. Pharmacogenetic testing: not as simple as it seems. Genet Med. 2008;10(6):391-395.

42. Henrikson NB, Burke W, Veenstra DL. Ancillary risk information and pharmacogenetic tests: social and policy implications. Pharmacogenomics J. 2008;8(2):85-89.

43. Netzer C, Biller-Andorno N. Pharmacogenetic testing, informed consent and the problem of secondary information. Bioethics. 2004;18(4):344-360

44. Voora D, Ginsburg GS. Clinical application of cardiovascular pharmacogenetics. J Am Coll Cardiol. 2012;60(1):9-20.

45. Tanzi RE. The genetics of Alzheimer disease. Cold Spring Harb Perspect Med. 2012;2(10). pii: 006296.

46. Haga SB, O’Daniel JM, Tindall GM, Lipkus IR, Agans R. Survey of US public attitudes toward pharmacogenetic testing. Pharmacogenomics $J$. 2012;12(3):197-204

47. Haga SB, O’Daniel JM, Tindall GM, Lipkus IR, Agans R. Public attitudes toward ancillary information revealed by pharmacogenetic testing under limited information conditions. Genet Med. 2011;13(8):723-728.

48. Cassini C, Thauvin-Robinet C, Vinault S, et al. Written information to patients in clinical genetics: what's the impact? Eur J Med Genet. 2011;54(3):277-280.

49. Essex C. Consultants could give patients a letter summarising their consultation. BMJ. 1998;316(7132):706.

50. Rao M, Fogarty P. What did the doctor say? J Obstet Gynaecol. 2007;27(5):479-480.

51. Hallowell N. Providing letters to patients. Patients find summary letters useful. BMJ. 1998;316(7147):1830

52. Baumanis L, Evans JP, Callanan N, Susswein LR. Telephoned BRCA1/2 genetic test results: prevalence, practice, and patient satisfaction. J Genet Couns. 2009;18(5):447-463.

53. Sangha KK, Dircks A, Langlois S. Assessment of the effectiveness of genetic counselling by telephone compared to a clinic visit. $J$ Genet Couns. 2003;12(2):171-184.

54. Harrison HF, Harrison BW, Walker AP, et al. Screening for hemochromatosis and iron overload: satisfaction with results notification and understanding of mailed results in unaffected participants of the HEIRS study. Genet Test. 2008;12(4):491-500 
55. Link E, Parish S, Armitage J, et al; SEARCH Collaborative Group. SLCO1B1 variants and statin-induced myopathy: a genomewide study. N Engl J Med. 2008;359(8):789-799.

56. Voora D, Shah SH, Spasojevic I, et al. The SLCO1B1*5 genetic variant is associated with statin-induced side effects. J Am Coll Cardiol. 2009;54(17):1609-1616
57. PharmGKB: Simvastatin [homepage on the Internet]. Stanford, CA: The Pharmacogenomics Knowledgebase; c2001-2013 [updated July 1, 2013]. Available from: http://pharmgkb.org/drug/PA451363. Accessed July 24, 2013. 


\section{Supplementary Figure}

An example of a patient letter for PGx testing following recommended content. Patient letters are routinely sent by genetic counselors to provide patients with an overview of the patient visit(s) and are separate from chart notes or letters to other physicians. Its primary purpose is to serve as a record of medical information and promote patient understanding.

\section{Dear Mr Smith,}

This letter is a summary of your visit where we discussed pharmacogenetic testing. The pharmacogenetic test was ordered because you were prescribed simvastatin (Zocor). Based on these results, a typical dose of simvastatin may not be the best [dose/medicine] for you. Therefore, I am [decreasing your dose/prescribing an alternative medicine].

You were prescribed simvastatin because of your elevated cholesterol and I would like to reduce your risk for developing cardiovascular disease. Common side effects for simvastatin include mild pain or discomfort, called myalgia. Side effects could also be more serious, like rhabdomyolysis, which is a condition where there is severe muscle damage and can, if untreated, be fatal. Environmental affects, like diet or other medicine may cause side effects. Changes in a gene that controls how simvastatin is broken down or metabolized can also lead to side effects.

The pharmacogenetic test for simvastatin is a genetic test that looks for changes in the gene that affects how simvastatin is handled by the body. These changes can cause simvastatin to be handled in a way that may cause side effects. To avoid side effects, patients with changes in the gene should be prescribed a lower dose of simvastatin or they should be prescribed a different statin.

Your pharmacogenetic test shows that you have a change in the gene that affects how your body handles simvastatin. Because of these results, I have chosen to [prescribe a lower dose/prescribe a different statin]. This should prevent side effects. However, please contact me immediately if you experience muscle pain.

It is important for you to remember your pharmacogenetic test results and share them with other doctors who prescribe medicine to you. The genetic change identified by the pharmacogenetic test may affect how your body handles other medicines. You may avoid having side effects from other medicines by sharing these results with other doctors.

I have also included a list of websites that have more information about pharmacogenetics and simvastatin if you are interested. Please let me know if you have any questions about your pharmacogenetic test result or the changes in your simvastatin prescription.

Figure SI Patient letter for PGx simvastatin testing.

Note: Data from.

\section{Reference}

1. PharmGKB: Simvastatin [homepage on the Internet]. Stanford, CA: The Pharmacogenomics Knowledgebase; c2001-2013 [updated July 1, 2013]. Available from: http://pharmgkb.org/drug/PA451363. Accessed July 24, 2013.

\section{Publish your work in this journal}

Pharmacogenomics and Personalized Medicine is an international, peerreviewed, open access journal characterizing the influence of genotype on pharmacology leading to the development of personalized treatment programs and individualized drug selection for improved safety, efficacy and sustainability. This journal is indexed on the American Chemical

Submit your manuscript here: http://www.dovepress.com/pharmacogenomics-and-personalized-medicine-journal
Society's Chemical Abstracts Service (CAS). The manuscript management system is completely online and includes a very quick and fair peer-review system, which is all easy to use. Visit http://www.dovepress. com/testimonials.php to read real quotes from published authors. 